\title{
Polyurethane Transparent Dressing Protection on the Insertion Area of Peripheral Intra Venous Catheter (PIVC)
}

\section{Septiana Fathonah and Maria Putri}

Notokusumo Nursing Academy

\section{Abstract}

One way to prevent infection in PIVC insertion is by dressing. Transparent polyurethane is one type of dressing that is often used in hospitals. Colonization of germs around the PIVC insertion area can cause infection. The objective of this study was to determine the difference in the number of germs in the PIVC insertion area with transparent polyurethane dressings in PKU Muhammadiyah Yogyakarta Hospital and to assess the effectiveness of dressing protection. The design of this study was quasi-experimental with a pretest-posttest design. The samples used are 11 patients and they are collected

Corresponding Author: Septiana Fathonah ninazahro@yahoo.com

Received: 18 January 2019 Accepted: 26 February 2019 Published: 12 March 2019

Publishing services provided by Knowledge E

(c) Septiana Fathonah and Maria Putri. This article is distributed under the terms of the

Commons Attribution License, which permits unrestricted use and redistribution provided that the original author and source are credited.

Selection and Peer-review under the responsibility of the 1st PANIHC Conference Committee. using purposive sampling. Calculation of the number of germs is carried out using the cup count method. The average number of germs before and after dressing using transparent polyurethane is decreasing in the average amount of 5.09. Analysis of the data using the Wilcoxon test is to determine the difference in the number of germs before and after the dressing. Statistical test results show that changes in the number of germs produced a $p$ value of 0.027 ( $p$ value <0.05). The results shows that there is a significant change in the number of germs in PIVC area before and after dressing using transparent polyurethane. The average number of germs after dressing with transparent polyurethane is lower. A subsequent research can be done with a stronger method of Rondomized Control Trial (RCT) with a larger number of samples.

Keywords: PIVC insertion area, transparent polyurethane dressing

\section{Introduction}

Peripheral Intra Venous Catheter (PIVC) is one of the invasive procedures that are often used by patients while undergoing treatment [1]. More than $80 \%$ of patients get intravenous therapy through PIVC and treatment therapy at the hospital setting [2]. Any invasive procedure can cause complications including the installation of PIVC. Local complications of PIVC include cellulitis, tissue infections, and osteomyelitis; plebitis or thromboplebitis; suppurative thromboplebitis; systemic infection [3]. 
Various parameters related to complications of PIVC insertion include catheter type, insertion site, skin preparation, dressing, length of installation [3]. One way to prevent infection in the extraluminal route of PIVC is by dressing method. Currently many dressing methods are used to prevent PIVC infection. One of them is using transparent polyurethane dressing. Transparent polyurethane dressing has the advantage of being able to see the wound state, maintain wound moisture, protect from external contamination, protect from friction, and it can be used as a second dressing over other types of dressings [4].

The purpose of this study is to determine the difference in the number of germs in the PIVC insertion area with transparent polyurethane dressing in PKU Muhammadiyah Hospital Yogyakarta and to assess the effectiveness of dressing protection.

\section{Methods and Equipments}

\subsection{Methods}

The research design used in this study is Quasi Experiment. Quasi Experiment used in this study is one group pretest-posttest design [5]. The population in this study were patients who carried out PIVC installation in several rooms at PKU Muhammadiyah Yogyakarta Hospital. Sampling in this study is non-random (non probability) namely random sampling. The sampling technique used is purposive sampling. Purposive sampling is done by taking the subject not based on strata, random or regional, but based on specific goals [6]. The number of samples in this study are 11 samples. This research has been carried out in several rooms at PKU Muhammadiyah Yogyakarta Hospital. The place for microbiological observation is conducted at Labkes Yogyakarta. The data collection process in this study was carried out in June-August 2018.

\subsection{Equipments}

The difference in the number of germs is the difference in the number of germs before and after observation which is measured either directly by a microscope or indirectly using a pouring plate [7]. The instrument used in this study is petri dish or petri dish. Petri dish is a small shallow dish used primarily in the field of microbiology for the cultivation of microorganisms in solid media. The synonym of this petri dish is petri plate [8]. Petri dishes are used to grow microbes. Petri dishes consist of two parts, namely the base and lid [9]. 


\section{Results}

\subsection{The characteristics of respondents}

The number of samples involved in this study are 11 samples. The following is the frequency distribution data of the characteristics of the research respondents including data on age and sex.

TABLE 1: Age Distribution and Gender of Patients Performed by PIVC with Transparent Polyurethane Dressing at PKU Muhammadiyah Yogyakarta Hospital $(n=11)$.

\begin{tabular}{l|l|c|c|}
\hline Variable & Categori & \multicolumn{3}{|c|}{ Samples (n=11) } \\
\hline Age & & $\mathbf{n}$ & $\%$ \\
\hline & 18-39 years & 1 & 9,1 \\
\hline \multirow{2}{*}{ Sex } & 40-61 years & 5 & 45,4 \\
\hline & 62-83 years & 5 & 45,4 \\
\hline & male & 10 & 90,9 \\
\hline
\end{tabular}

Based on table 1, the majority of respondents aged 40-61 years are 5 people (45.4\%) and $62-83$ years old are 5 people (45.4\%). The sex of the majority of respondents is 10 male (90.9\%).

\subsection{The characteristics related to PIVC insertion in patients}

The characteristics related to PIVC placement in patients based on PIVC insertion and treatment space. The following is the frequency distribution of PIVC patient installations based on insertion room and PIVC treatment:

TABLE 2: Distribution of insertion room and PIVC treatment at PKU Muhammadiyah Yogyakarta Hospital (n $=11)$.

\begin{tabular}{l|l} 
Variable & Category \\
& \\
\hline PIVC Installation Room & $\begin{array}{l}\text { Arofah Inpatient Ward } \\
\text { Marwah Inpatient Ward } \\
\end{array}$ \\
\hline Emergency Room \\
\hline PIVC Treatment Room & $\begin{array}{l}\text { Arofah Inpatient Ward } \\
\text { Marwah Inpatient Ward } \\
\end{array}$ \\
& Raudoh Inpatient Ward
\end{tabular}

\begin{tabular}{|c|} 
Intervension \\
Group (n=11) \\
\hline $\mathbf{n}$ \\
\hline 4 \\
\hline 0 \\
7 \\
\hline 4 \\
\hline 5 \\
\hline 2
\end{tabular}

Percent
$\%$
36,4
0
63,6
36,4
45,4
18,2


Based on Table 3.2 it is known that the majority of PIVC installation rooms in the Emergency Room are 7 people (63.6\%) and the majority of PIVC treatment rooms in the Marwah Inpatient ward are 5 people (45.4\%).

\subsubsection{Overview of the number of germs in the PIVC insertion area before and after dressing using Transparent Polyurethane}

The following is a description of the number of germs in the PIVC insertion area before and after dressing using Transparent Polyurethane at PKU Muhammadiyah Yogyakarta Hospital, which is indicated in the following Table 3:

TABLE 3: Overview of the Number of Germs in the PIVC Insertion Area Before and After Dressing in Using Transparent Polyurethane at PKU Muhammadiyah Hospital in Yogyakarta $(n=11)$.

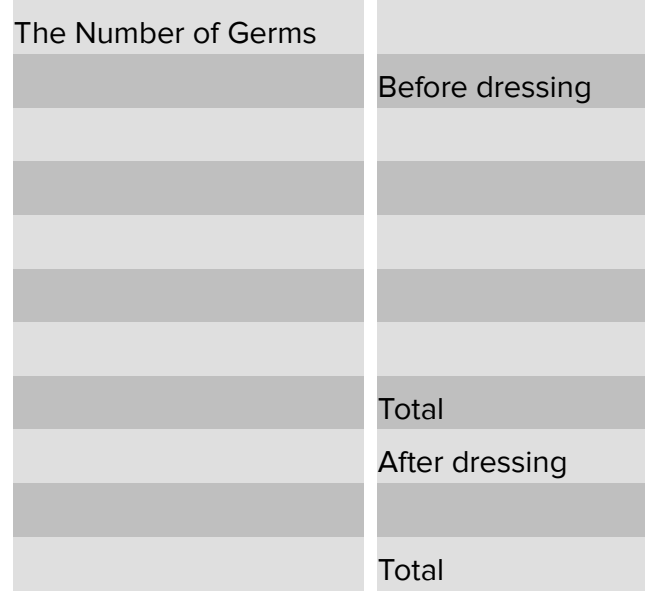

\begin{tabular}{|c|c|c|}
\hline & Frequensi & Percent (\%) \\
\hline 1 & 5 & 45,5 \\
\hline 2 & 2 & 18,2 \\
\hline 4 & 1 & 9,1 \\
\hline 7 & 1 & 9,1 \\
\hline 11 & 1 & 9,1 \\
\hline 38 & 1 & 9,1 \\
\hline & 11 & 100 \\
\hline 3 & 10 & 90,9 \\
\hline & 1 & 9,1 \\
\hline
\end{tabular}

Table 3 describes that the number of germs prior to dressing using Transparent Polyurethane is at least 1 obtained from 5 patients (45.5\%) and the highest number of germs was 38 obtained from 1 patient (9.1\%). While the number of germs after the Transparent Polyurethane dressing is at least 1 obtained from 10 patients (90.9\%) and the maximum number of germs 3 obtained from 1 patient (9.1\%).

\subsection{The changes in the number of germs in the PIVC installation area before and after dressing using Transparent Polyurethane}

Based on normality tests performed on the number of germs before and after dressing using Transparent Polyurethane, the result is $p=0.00(p<0.05)$, the data is not normally distributed. So that the bivariate statistical test to test changes in the number of germs in the PIVC installation area before and after dressing using Transparent Polyurethane is the Wilcoxon test. Statistical test results are shown in the table below: 
TABLE 4: Changes in the Number of Germs in the PIVC Installation Area Before and After Dressing Using Transparent Polyurethane at PKU Muhammadiyah Hospital in Yogyakarta $(n=11)$.

\begin{tabular}{l|l|l|l|l|l|l|l|}
\hline The Number of Germs & & $\mathrm{n}$ & $\%$ & mean & SD & Min-Maks & p value* \\
\hline & Before & 11 & 100 & 6,27 & 11,001 & $1-38$ & 0,027 \\
\hline & After & 11 & 100 & 1,18 & 0,603 & $1-3$ & \\
\hline * $p$ value if $<0,05$ & & & & & & &
\end{tabular}

Based on table 4 the average value of the number of germs between before and after dressing using transparent polyurethane, there is a decrease in the average amount of 5.09. Statistical test result shows that changes in the number of germs produce $p$ value of 0.027 ( $p$ value $<0.05$ ). This shows that there is a significant change in the number of PIVC area germs between before and after dressing using transparent polyurethane.

\section{Discussion}

Based on the description of the research respondents in the previous chapter that the majority of respondents 40-61 years of age is 5 people (45.4\%) and 62-83 years 5 people (45.4\%). The average age of patients who are attached to PIVC included in the Soifer et al [10] study is 58 (in the house staff group) and 60 (in the IV team group). The older age group is hospitalized and are treated with therapy, one of which is by installing PIVC. The sex of the majority of respondents is 10 male (90.9\%). This is the same as the study by Soifer et all [10] of the total 87 patients who are put on PIVC in the house staff group group of 44 male patients.

The majority of PIVC installation rooms in the Emergency Room are 7 people (63.6\%) and the majority of PIVC treatment rooms in the Marwah Inpatient Room are 5 people (45.4\%). In PKU Muhammadiyah Yogyakarta Hospital, the installation of PIVC was carried out in two rooms, namely the Emergency Room and the living room. PIVC installation and treatment at PKU Muhammadiyah Hospital in Yogyakarta uses one SOP for the installation process by nurses although the location of the installation and maintenance is different.

The number of germs before dressing using Transparant Polyurethane was at least 1 obtained from 5 patients (45.5\%) and the highest number of germs obtained was 38 from 1 patient (9.1\%). While the number of germs after the Transparent Polyurethane dressing was at least 1 obtained from 10 patients (90.9\%) and the maximum number of germs 3 obtained from 1 patient (9.1\%). Based on the results of the study, the highest number of germs in the PIVC insertion area after Transparent Polyurethane dressing was less in number than before dressing. Transparent polyurethane is semipermeable which is 
able to prevent bacterial, viral, other foreign matter contamination and water resistance while maintaining skin breathing, so that it can maintain skin integrity. This confirms that transparent polyurethane dressing has the advantage of protecting against external contamination [4].

The average number of germs between before and after dressing using Transparent Polyurethane was a decrease in the average number of 5.09. Statistical test results show that changes in the number of germs produce a $p$ value of 0.027 ( $p$ value $<0.05$ ). This shows that there is a significant change in the number of PIVC area germs between before and after dressing using transparent polyurethane. Infection in PIVC is caused by normal bacterial flora on the skin that move to the insertion area. As many as $70 \%$ of the bacteria Staphylococcus epodermidis is the cause of PIVC infection, and found also the bacterium Stapylococcus aureus [11]. Dressing with transparent polyurethane has advantages and disadvantages. Transparent dressing (for example: Op-Site, Tegaderm, Bioclusive) has the advantage of being able to see the wound state, prevent moisture loss from injury, protect from external contamination, protect from friction, can be used as a second dressing over other types of dressings. While the weakness is not absorbing, it may produce maceration of the edges of wound tissue [4]. Transparent polyurethane is able to protect the PIVC insertion area from infection. Based on research conducted by Madeo et al. [12] it is known that transparent polyurethane is able to protect the PIVC insertion area after 72 hours when compared to gauze dressing.

In this study, there was a significant decrease in germs in the PIVC insertion area. This can be caused by the dressings with transparent that can cover perfectly the PIVC insertion area. In addition, transparent polyurethane is semipermeable which can prevent germs, virus, other foreign matter contamination and water while maintaining skin breathing, so as to maintain skin integrity. This confirms that transparent polyurethane dressing has the advantage of protecting against external contamination [4]. Based on the important criteria (SSIVD), it states that the use of transparent dressing is the right choice of dressing to minimize the risk of infection [13]. In addition, by using transparent polyurethane dressing, it can minimize damage to skin integrity, risk of trauma, and infection. Transparent polyurethane can be used for a maximum of 7 days [14]. Thus it is clear that dressings with transparent polyurethane according to SOP is effective for protecting against germ contamination. 


\section{Conclusion}

The conclusion of this study is that there is a significant difference in the number of germs in the PIVC insertion area before and after dressing using transparent polyurethane where the average number of germs after transparent polyurethane dressing is lower than before. This type of dressing can be used for PIVC dressing in patients as an effort to protect from microorganisms that cause infection. Dressing with Transparent Polyurethane according to SOPs is effective to protect from germ contamination. Suggestions for the next research is that it should be done with a stronger method of Rondomized Control Trial (RCT) with a larger number of samples in treatment settings in Indonesia.

\section{Funding}

This work was supported by Director of Research and Community Service (DRPM) of the Directorate General of Higher Education of the Republic of Indonesia

\section{Acknowledgement}

The authors would like to thank their colleague for their contribution and support to the research. They are also thankful to all the reviewers who gave their valuable inputs to the manuscript and helped in completing the paper

\section{Conflict of Interest}

The authors have no conflict of interest to declare.

\section{References}

[1] Gonzales Lopez, JL, Arribi Vilela A, Fernandez del Palacio E, Olivares Corral J, Complications and cost of open vs close safety peripheral intravenous catheters: a randomized study. J Hosp Infect. 2014;86(2):117-26.doi:10.106/j.jhin.2013.10.008. (PubMed:24373830).

[2] Pasalioglu KB, Kaya H. Catheter indwell time and phlebitis development during peripheral intravenous catheter administration. Pak J Med Si..2014;30(4):72530.(PubMed:25097505) 
[3] Lynn Hadaway, Short peripheral intravenous catheters and infections. Journal of Infusion Nursing. 2012; Vol 35; Number 4. doi:10.1097/NAN/Ob013e31825sf099

[4] Baird, M.S. \& Bethel, S. 2011. Manual of Critical Care Nursing Nursing Interventions and Collaborative Management. St Louis Missouri: Elsevier Mosby

[5] Polit, D.F. \& Beck, C.T. 2004. Nursing Research Principles and Methods Seventh Edition. United State of America: Lippincott Williams and Wilkins.

[6] Arikunto, S. 2010. Prosedur Penelitian Suatu Pendekatan Praktik. Jakarta: Rineka Cipta.

[7] Gillespie, S. \& Bamford, K. 2009. At a Glance Mikrobiologi Medis dan Infeksi. Terjemahan Stella Tinia. Jakarta: Penerbit Erlangga.

[8] Mosby's Dental Dictionary (2nd ed.). Elsevier. 2008. Diakses tanggal 13 Februari 2014.

[9] Waluyo, L. 2010. Teknik dan Metode Dasar dalam Mikrobiologi. Malang: UMM Press.

[10] Soifer, N. E., Borzak, S., Edlin, B. R., \& Weinstein, R. A. (1998). Prevention of peripheral venous catheter complications with an intravenous therapy team: a randomized controlled trial. Archives of Internal Medicine, 158(5), 473-477.

[11] M.Pujol, A.Hornero, M.Saballs, et al. Clinical epidemiology and outcomes of peripheral venous catheter-related bloodstream infection at a university-affiliated hospital. J Hosp Infect, 67. 2007, pp 22-29.

[12] M.Madeo, C. Martin, A. Nobbs. A randomized study comparing IV 3000 (transparent polyurethae dressing) to a dry gauze dressing for peripheral intravenouse catheter site. J Intraven Nurs, 20 (5). 1997, pp 253-256.

[13] Kergon, E. \& Obasi C. 2010. Guidelines for the Management of Central Venous Catheters in Adults. Bradford and Airedale Community Health Services.

[14] H.Wisplinghoff, T. Bischoff, S.M. Tallent, et al. Nosocomial bloodstream infection in US hospitals: analysis of 24,179 cases from a prospective nationwide surveillance study. Clin Infect Dis, 39(3);2004, pp 309-317. 